\title{
Effectiveness of Flip Teaching Strategy on Academic Achievement of Student Teachers
}

\author{
Himanshu Tripathi ${ }^{1 *}$
}

\section{ABSTRACT}

The concept of Flipped classroom is based on the concept of active learning, student engagement, hybrid course design and course podcasting. The classroom becomes a workshop where interaction among Educator and students takes place. Since effectively flipping a classroom brings many benefits, it will provide opportunities to B.Ed student teachers to learn at their own pace easily. In this study, B.Ed student teachers from two different teacher training institutes were randomly selected (22 from each having Economics as their optional teaching subject). In an institute, 11 students out of 22 were randomly assigned as the control and rest as the experimental group. So, 22 students were in the control and the experimental group combining both the institutes. The result in this strategy seems to be effective in teaching Economics by student teachers, without any monetary burden in creating active learning environment in the classroom.

Keywords: Effectiveness, Flip Teaching Strategy, Academic Achievement, Student Teachers

The Flipped classroom seems to be one of the latest fashion in teaching-learning process. Sometimes it is the reverse gear that helps us to take out our vehicle out of a pit and then proceed smoothly a head on the highway. Flipping the classroom refers to another form of Blended Learning where a student is tasked with homework usually via a video or audio file. The classroom time is spent clarifying and applying new knowledge through problem solving and discussion method. Flipped instruction is also known as backwards classroom, reverse instruction or reverse teaching.

The concept of Flipped classroom is based on the concept of active learning, student engagement and hybrid course design and course podcasting. The classroom becomes a workshop where interaction among Educator and students takes place. Students are encouraged for individual inquiry and collaborative effort. We can say that a Flipped classroom stands on four pillars:

\footnotetext{
${ }^{1}$ Research Scholar (Education), Alagappa University, Karaikudi, India *Responding Author

(C) 2016 I H Tripathi; licensee IJIP. This is an Open Access Research distributed under the terms of the Creative Commons Attribution License (http://creativecommons.org/licenses/by/2.0), which permits unrestricted use, distribution, and reproduction in any Medium, provided the original work is properly cited.
} 
Effectiveness of Flip Teaching Strategy on Academic Achievement of Student Teachers

\begin{tabular}{|c|c|c|c|}
\hline Flexible Environment & Learning Culture & Intentional Content & Professional Educator \\
\hline $\begin{array}{l}\text { Flipped Learning creates } \\
\text { flexible spaces in which } \\
\text { students choose when and } \\
\text { where to learn. Educators } \\
\text { esatablish spaces and the } \\
\text { time frames that permit } \\
\text { students to interact. They } \\
\text { continually observe, } \\
\text { monitor and provide } \\
\text { students with different } \\
\text { ways to learn content. }\end{array}$ & $\begin{array}{l}\text { Flipped Learning model } \\
\text { deliberately shifts } \\
\text { instruction from teacher } \\
\text { centred to a learner- } \\
\text { centered approach, } \\
\text { where topic is explored } \\
\text { in depth. In turn it } \\
\text { creates an actively } \\
\text { involved environment } \\
\text { where knowledge is } \\
\text { firmly constructed. }\end{array}$ & $\begin{array}{l}\text { Educators } \\
\text { intentionally } \\
\text { model to } \\
\text { Flipped } \\
\text { develop } \\
\text { understanding as well as } \\
\text { procedural fluency in } \\
\text { students. Educators use } \\
\text { Intentional content } \\
\text { which is student- } \\
\text { centered and adopts } \\
\text { active learning strategies. }\end{array}$ & $\begin{array}{l}\text { The role of a Professional } \\
\text { Educator is to continually } \\
\text { observe their students, } \\
\text { provide them with } \\
\text { feedback in real time as } \\
\text { needed and assess their } \\
\text { work by conducting } \\
\text { formative assessments } \\
\text { during class time through } \\
\text { observation and by } \\
\text { recording data to transform } \\
\text { future instruction. }\end{array}$ \\
\hline
\end{tabular}

\section{Need of Flip in Teaching Economics:}

According to Bloom (1984), "an average student who receives one-on-one attention is enabled by constant feedback, corrective process and can jump into the 98th percentile of the student population in academic achievement” (Houston and Lin, 2012). This was stated 32 years ago but most classes are still taught with teacher-centered lectures and only the persistent students seek out one-on-one assistance. Perhaps the first research relating to Flipped classrooms in undergraduate Economics education is Lage et al. (2000). Maxwell et al. (2005) find that when problem-based learning is used in a large sample of High School Economics students, their performance may increase if teachers are properly trained in both the new teaching techniques and in Economics. The Flipped format has allowed us to cover more material. For example, in the principles of Macroeconomics class when Flipped strategy is used, there is sufficient time to add a unit dealing with International Economics. This was also found by Bland (2006) who was also able to cover more material in a Flipped classroom compared with a traditional lecture based system of teaching. Yamarik (2007) compared two Economics courses, one taught in traditional lecture format and one with cooperative learning. He found that student's performance on exams was higher in cooperative learning. Roach (2014) found that students reacted positively to the use of a Flipped classroom in principles of Microeconomics class. Calimeris and Sauer (2014) present empirical evidence that in a randomized experiment, "following a negative adjustment period, students who experienced the Flipped teaching method scored significantly higher on midterm and final exams than did the control group.” Thus Economics teaching research appears suggest that students react positively to the use of a Flipped classroom and definitely it increases their performance. 
Again, two of the problems that could stand in the way of an instructor not experimenting with the use of a Flipped classroom are the fixed cost problem and the inertia problem. The fixed cost problem relates mainly to the work it takes to make the videos that students watch before class. In this study investigator tried to provide link to the sample that is already available on internet. To enhance active learning in the classroom educators should divide students in small groups and try to interact with each group. Each group should to be motivated to interact with each other. Moreover educators should also be trained in the new strategy. This will help him in creating the learning environment more active.

Since effectively flipping a classroom brings many benefits, it will provide opportunities to B.Ed student teacher to learn at their own pace easily. So the researcher decided to choose the topic "Effectiveness of Flip Teaching Strategy on Academic Achievement of Student Teachers".

\section{Objectives:}

(i) To develop Flip teaching strategy for B.Ed student teachers in teaching Economics.

(ii) To find out if there is any significant difference in academic achievement of the control and the experimental group before and after applying the Flip strategy.

(iii) To find out if there is any significant difference in attainment of knowledge and application of the content between the control and the experimental group.

\section{Hypotheses:}

(i) There is no significant difference in the pre-test scores of the control and the experimental group of student teachers.

(ii) There is no significant difference in the post-test scores of the control and the experimental group of student teachers.

(iii) There is no significant difference in attainment of knowledge and application of the content taught between the control and experimental group post teaching.

\section{METHODOLOGY}

B.Ed student teachers from two different teacher training institutes were randomly selected (22 from each having Economics as their optional teaching subject). In an institute, 11 students out of 22 were randomly assigned as control and rest as the experimental group. So, 22 students were present in the control and the experimental group combining both the institutes.

A pre-test was conducted in both the control and experimental group. Control group was taught with conventional Lecture method and the experimental group was taught with the Flip strategy. Later a post test on the same achievement test was conducted for both the groups in order to check the effectiveness of the Flip strategy.

\section{Sample:}

(c) The International Journal of Indian Psychology, ISSN 2348-5396 (e)| ISSN: 2349-3429 (p) | 84 


\section{Effectiveness of Flip Teaching Strategy on Academic Achievement of Student Teachers}

44 participants from two different Teacher Training Colleges of Trivandrum district in Kerala were selected. Economics Teaching is their optional subject at B.Ed level. The two colleges were GCTE Thycud and St. Thomas Training College Mukkolakkal, Trivandrum.

\section{Tools:}

- Achievement test (50 questions on Microeconomics- Law of Supply and Demand was constructed and validated by the researcher, equally divided into knowledge and application category).

- The link of Khan Academy which has already prepared video lessons on Micro EconomicsLaw of Demand and Law of Supply was provided to the experimental group.

https:/www.khanacademy.org/economics-finance-domain/microeconomics/supply-demandequilibrium/demand-curve-tutorial/v/law-of-demand https://www.khanacademy.org/economics-finance-domain/microeconomics/supply-demandequilibrium/supply-curve-tutorial/v/law-of-supply

\section{Statistical Techniques Used:}

- Mean and Standard deviation

- t-test to determine the significant difference between the means of the control group and the experimental group.

\section{HYPOTHESES TESTING}

(i) There is no significant difference in the pre-test scores of the control and the experimental group Student teachers.

\begin{tabular}{|l|l|l|l|l|}
\hline Group & Mean & SD & t-value & Remarks \\
\cline { 1 - 3 } Control & 14.46 & 2.23 & \multirow{2}{*}{1.623} & Not significant* \\
\hline
\end{tabular}

*.05 level

So, hypothesis is correct and accepted that there is no significant difference in the pre-test scores of the control and experimental group student teachers. Both the groups are at par in terms of the content knowledge before teaching. From the table data it is evident that performance of both the groups in achievement test is below average.

(ii) There is no significant difference in the pre-test scores of the control and experimental group.

\begin{tabular}{|l|l|l|l|l|}
\hline Group & Mean & Std Dev & t-value & Remarks \\
\hline Control & 21.96 & 1.47 & \multirow{2}{*}{21.25} & \multirow{2}{*}{ Significant* } \\
\cline { 1 - 4 } Experimental & 35.97 & 2.72 & & \\
\hline
\end{tabular}

*.01 level 


\section{Effectiveness of Flip Teaching Strategy on Academic Achievement of Student Teachers}

So, hypothesis is rejected as there is significant difference in the post test scores of the control and experimental group teacher trainees. Experimental group was benefitted largely with the Flip method of teaching.

(iii) There is no significant difference in attainment of knowledge and application of the content taught between the control and experimental group post teaching.

\begin{tabular}{|c|c|c|c|c|c|c|}
\hline \multirow{2}{*}{ Group } & \multicolumn{2}{|c|}{ Control Group } & \multicolumn{2}{|c|}{$\begin{array}{l}\text { Experimental } \\
\text { Group }\end{array}$} & \multirow[t]{2}{*}{ t-value } & \multirow[t]{2}{*}{ Remarks } \\
\hline & Mean & SD & Mean & SD & & \\
\hline Knowledge & 12.79 & 2.47 & 17.46 & 2.67 & 6.022 & Significant* \\
\hline Application & 9.17 & 0.47 & 18.51 & 2.77 & 15.59 & Significant* \\
\hline
\end{tabular}

*.01 level

So, this can be concluded that there is significant difference in attainment of knowledge and application of the content taught between control and experimental group. Moreover, it should be noted that more benefit is seen at application of the content taught in the experimental group.

\section{CONCLUSION}

With the passage of time and technology, there has been a tremendous shift in the paradigm of teaching. Demand for active learning is increasing which in turn increases student's performance. One of the most popular applications of active learning is the Flipped classroom. Here topics are introduced to students in video format before classroom teaching and the class time is spent on active learning exercises. Though the cost of using such techniques was always questioned. Through this paper researcher tried to show that both the inertia problem and the fixed cost problem are smaller than they are thought. Thus, Economics teacher should experiment with a Flipped classroom by experimenting with a single lecture. We can watch videos prepared by the Khan Academy. In addition, the active learning exercises can focus on problem based learning which should identify the single lecture in a course that might be well suited in turning it into a Flipped classroom. This strategy seems to be an effective one in teaching Economics by student teachers, without any monetary burden in creating active learning environment in the classroom.

\section{Acknowledgments}

The author appreciates all those who participated in the study and helped to facilitate the research process.

\section{Conflict of Interests}

The author declared no conflict of interests. 


\section{REFERENCES}

Calimeris, L., \& Sauer, K. M. (2014). Flipping Out About the Flip: All Hype or is There Hope? Available at SSRN 2481975.

Lage, M. J., Platt, G. J., \& Treglia, M. (2000). Inverting the classroom: A gateway to creating an inclusive learning environment. The Journal of Economic Education, 31(1), 30-43.

Maxwell, N. L., Mergendoller, J. R., \& Bellisimo, Y. (2005). Problem-based learning and high school macroeconomics: A comparative study of instructional methods. The Journal of Economic Education, 36(4), 315-329.

Roach, T. (2014). Student perceptions toward flipped learning: New methods to increase interaction and active learning in economics. International Review of Economics Education, 17, 74-84.

Yamarik, S. (2007). Does cooperative learning improve student learning outcomes? The journal of economic education, 38(3), 259-277.

How to cite this article: $H$ Tripathi (2016), Effectiveness of Flip Teaching Strategy on Academic Achievement of Student Teachers, International Journal of Indian Psychology, Volume 3, Issue 4, No. 57, ISSN 2348-5396 (e), ISSN: 2349-3429 (p), DIP: 18.01.028/20160304, ISBN: 978-1-365-23993-9 